Esta revista forma parte del acervo de la Biblioteca Jurídica Virtual del Instituto de Investigaciones Jurídicas de la UNAM www.juridicas.unam.mx

www.bibliojuridica.org

PROBLEMA

Anuario de Filosofia

y Teoría del Derecho

\title{
REASONS IN ACTION $v$ TRIGGERING-REASONS: A REPLY TO ENOCH ON REASON-GIVING AND LEGAL NORMATIVITY
}

\author{
Veronica RODRIGUEZ-BLANCO*
}

\section{Resumen:}

El problema central de la 'normatividad del derecho' versa sobre cómo las reglas o directrices jurídicas nos dan razones para la acción. El núcleo de esta cuestión reside en cómo algo que es externo al agente, tal como las reglas o directrices jurídicas, pueden ser 'parte del agente', y cómo pueden guiar a ese agente al llevar a cabo acciones complejas (tal como la obediencia de las reglas) que persisten en el tiempo. David Enoch ha negado que la normatividad del derecho presente algún reto interesante a las teorias del derecho. Arguye que el derecho provee razones para la acción en términos de lo que él llama razones detonantes (triggering-reasons) y propone la perspectiva de que, dado que hay muchas circunstancias bajo las cuales se detonan las razones, el derecho no plantea ningún reto especial. De acuerdo con Enoch, una vez que entendemos la manera en que operan las razones detonantes, podemos comprender cómo las reglas y directrices jurídicas nos proveen razones para la acción. En la sección II de este artículo, fijo el escenario para el debate y establezco una serie de principios que emergen de la visión de sentido común sobre las razones para las acciones, y sostengo que cualquier teoría de las razones para la acción debería proporcionar una explicación coherente de estos principios clave. Me centro en la idea de que una concepción satisfactoria de las razones para la acción también debería explicar las razones en las acciones. En la sección III, explico brevemente las diferentes teorías de las razones para la acción y ubico la concepción de Enoch de razones para la acción como razones detonantes

* Senior Lecturer, School of Law, University of Birmingham. I am grateful to Geoff Callaghan, Mark Johnstone, Heather Kuiper and Stefan Sciaraffa for comments and discussions on the paper. 


\title{
VERONICA RODRIGUEZ-BLANCO
}

(triggering-reasons) dentro de este marco teórico. En la sección IV muestro que la concepción de Enoch de razones para las acciones no explica algunas de las principales características o principios que emergen de nuestra visión de las razones para la acción basada en el sentido común, ni tampoco explica las razones en las acciones.

\section{Palabras clave:}

Normatividad del derecho, razón práctica, normas.

\begin{abstract}
:
The central problem of the 'normativity of law' concerns how legal rules or directives give us reasons for actions. The core of this question is how something that is external to the agent, such as legal rules or directives, can be 'part of the agent', and how they can guide the agent in performing complex actions (such as legal rule-following) that persist over time. David Enoch has denied that the normativity of law poses any interesting challenge to theories of law. He argues that law provides reasons for actions in terms of what he calls triggering-reasons and he advances the view that because there are many circumstances in which reasons are triggered, law does not pose a special challenge. According to Enoch, once we understand the way that triggering reasons operate, we can understand how legal rules and directives provide us with reasons for actions. In $\S$ II of this paper, I set the stage for the debate and establish a set of principles that emerge from the common sense of view of reasons for actions and argue that any theory of reasons for action should provide a coherent explanation of these key principles. I focus on the idea that a satisfactory account of reasons for action should also explain reasons in actions. In $\S$ III I explain briefly the different theories of reasons for action and locate Enoch's conception of reasons for action as triggering-reasons within this theoretical framework. In $\S I V I$ show that Enoch's conception of reasons for actions does not explain some of the key features or principles that emerge from our common sense view of reasons for action and nor does it explain reasons in actions.
\end{abstract}

\section{Keywords:}

Normativity of Law, Practical Reason, Norms. 
Summary: I. Introduction. II. Setting the Stage for the Debate. III. Theories of Reasons for Actions. IV. Putting Normativity in Its Place.

\section{INTRODUCTION}

The problem of how legal rules or directives give us reasons for actions is the central problem of what has been called the 'normativity of law'. 1

The central question of legal normativity is how something that is external to the agent, such as legal rules or directives, can be 'part of the agent' and guide the agent in the performance of complex actions that persist over time. There are, however, different understandings of what 'being part of the agent' means. It could be that 'being part of the agent' consists of beliefs, desires, intentions, attitudes or a combination of all of these. Other authors prefer to say that the question is how legal rules and directives enter into the practical reasoning of the addressees of legal rules and directives. ${ }^{2}$

David Enoch, however, has denied that the normativity of law poses any substantial challenge to theories of law. ${ }^{3} \mathrm{He}$ argues that law provides reasons for actions in terms of what he calls 'triggering-reasons' and argues that robust reason-giving, e.g. in the ethical domain and in law, are kinds of reason-giving as triggering reasons. Consequently,

1 Raz, J., Engaging Reasons (Oxford: OUP: 1999).

2 Raz, J., Practical Reasons and Norms (Princeton University Press, 2nd Edition, 1990).

3 Enoch, D., "Reason-Giving and the Law". In: Oxford Studies in Philosophy of Law (edited by Green, L. and Leiter, B., Oxford University Press, 2011). A further detailed account of Enoch's triggering-reasons approach can be found in his article "Giving Practical Reasons", in 11 Philosopher's Imprint 4 (2011). For a clear exposition and defence of Enoch's view see Bix, B., "The Nature of Law and Reasons for Action", in Problema. Anuario de Filosofía y Teoría del Derecho, No. 5, 2011, 399-415, e-journal available at $h t t p: / / w w w$. juridicas.unam. $m x /$ publica/rev/cont.htm? $r=f i l o$ tder\& $n=5$. 
because there are many circumstances in which reasons are triggered, the law does not pose a special challenge. Once we understand the way that triggering reasons operate we can understand how legal directives and legal rules provide us with reasons for actions. Furthermore, according to Enoch, legal positivism is in the best position to explain the reason-giving character of the law in terms of what he considers the sound account of reason-giving, i.e. triggering reasons. In $\S$ II of this paper I set the stage for the debate by establishing a set of principles that emerge from the common sense view concerning reasons for actions. I argue that any theory of reasons for action should provide a coherent explanation of the different features or principles that emerge that from the common sense view, and I focus on the idea that a satisfactory account of reasons for action should also explain reasons in actions. In § III I explain briefly the different theories of reasons for action and locate Enoch's conception of reasons for action as triggering-reasons within this theoretical framework. In § IV I show that Enoch's conception of reasons for actions does not explain some of the key features or principles of our common sense view on reasons for action and nor does it explain reasons in actions. Consequently triggering-reasons for action is neither a sound account of legal normativity and nor does it explain the phenomenon of reason-giving. The conclusion is that we should attempt to provide a complete account of the reason-giving phenomenon and then elaborate a theory of law which most adequately fits this account. Enoch's methodology goes in the opposite direction, that is to say that he attempts to find the most plausible account of reasons for action that best fits his own favoured theory of law, i.e. legal positivism. Unsurprisingly the account of reasons for action that emerges is implausible.

\section{Setting the Stage for the Debate}

Let us begin with the following example provided by Enoch (with some expansion and variations): 
'BUYING MILK': On most Mondays, you wake up in the morning, you wake up your friend, take the keys to your vehicle, and you both drive to the local grocery store. You get out of your vehicle, enter the grocery store, find the milk in the fridge and buy two bottles. But today is different. You and your friend drive to the local grocery store and in an unusual move, you choose to buy one bottle of milk instead of two. When your friend sees that you have chosen one bottle of milk instead of two, he asks you 'Why'? Your answer is that the price of milk has risen and you wish to save money. Your friend asks you why you wish to save money and your answer is that you intend to travel to South America in the summer. He asks you again why? and you answer that you find travelling attractive and a good learning experience. The elucidation of the reasons for action from the point of view of the agent, i.e. the deliberative point of view, can now stop or rest. The series of complex actions, i.e. waking up on that Monday, driving to the local grocery store and buying one bottle of milk, finds an end that is presented to the agent as having good-making characteristics. The reason for buying one bottle of milk is that you intend to save money and you intend to save money because you intend to travel to South America. You intend to travel to South America because you find travelling attractive and a good learning experience.

In this case, the reason for saving money to travel to South America is both a justificatory and explanatory reason for your series of actions. It is explanatory because it explains why you did what you did and it is justificatory because it can be subject to praise or blame. You can be judged by your friend as financially wise or as not supporting the local economy and caring for local farmers. The reason also guided you in your action and therefore the reason was in the action. This means that because you intended to save money, you selected one bottle and not two. Let us imagine a slightly different scenario from "BUYING MILK". Let us call it "ADVICE FROM A FRIEND". Let us suppose that ex- 
actly the same things happen as in "BUYING MILK", but when you are about to select your bottle of milk, your friend looks at his iPhone and sees that at another store, half a mile away, the milk is half price. Therefore you return the bottle of milk to the fridge, leave the store, drive for a mile and go to the other grocery store to buy the cheaper milk. You do all this because you have the reason of saving money to travel to South America. The reasons are in the action and when the agent performs the complex action. Because of your reason of saving money, you persist in your actions and are able to circumvent obstacles. Let us suppose that the second grocery store is closed when you arrive. It will open in thirty minutes so you wait until it opens.

The examples that I have given are paradigmatic examples of reasons for action and reasons in action, where justificatory and explanatory reasons for action are one and the same. Reasons guide the action of the agent and are present in the agent when she circumvents obstacles and persists in her actions over time. Cheap prices give you reasons to buy the items or, as Enoch puts it, the grocer, by putting up the price of milk, has given you a reason to drive until you find cheaper milk.

The example reflects our common sense view of reasons for action and establishes four different key features or principles of reasons for actions: a) explanation; b) justification; c) guidance; and d) persistence over time. Let us again concentrate on our example "ADVICE FROM A FRIEND": if you suffer from temporary amnesia and forget that you intend to save money while you are at the first grocery store, then you will not drive to the second grocery store and wait until it is opened, you will desist instead of persist in your actions. You will drive home and do something else. Features of the world guide you in your actions, you are able to track cheap prices and you are justified in doing so because it is a good thing to save money. Furthermore, in providing the reason of saving money you have made intelligible the unity and continuity of your actions. 


\section{THEORIES OF REASONS FOR ACTIONS}

In rough terms one might say that there are three main theories of reasons for actions and that they differ according to how they privilege the key features or principles of the common sense view. First, normativists ${ }^{4}$ begin with the question of what we have most reason to want or do and how agents act for good reasons.

According to this view, a normative reason is a reason that is in favour of an action and normativists assert that one has normative reasons for action independently of our motivations or psychological make-up, i.e. desires. Normativists claim that we deliberate and gain possession of our reasons for action through a theoretical exercise. In the case of 'BUYING MILK', for example, the reasons that make travelling worthwhile are understood and so is the value of money and the importance of saving. Normativists privilege the justificatory features of the common sense view over the explanatory, guidance and persistence features. Thus, if the explanatory and justificatory features separate from one another, then normativists (would) assert that the reasons in favour of the action independently of the explanation provided by the agent are the reasons for actions. The problem is that if normative reasons provide the required justificatory reasons for action independently of the explanatory reasons for actions from the agent's point of view, then how can the persistence of complex actions over time be explained? Normativists can explain justificatory reasons for action, but not reasons in the action and when the agent acts. In other words they cannot explain the reasons that the agent had and on the basis of which he persisted in his actions. Furthermore, control and guidance are interconnected. The reason needs to be transparent to the agent from the deliberative point of view in order to be able to guide the agent and for the agent to be in control of his rea-

4 Dancy, J., Practical Reality (Oxford University Press, 2000); Scanlon, T., What we Owe to Each Other (Harvard University Press, 1998). 
sons during the action. This is a consequence of the two different directions of fit between theoretical and practical knowledge. I shall explain this point further.

How should we draw the distinction between practical and theoretical knowledge? Let us take a modified version of the example provided by Anscombe in Intention. ${ }^{5}$ A man is asked by his wife to go to the supermarket with a list of products to buy. A detective is following him and makes notes of his actions. The man reads in the list 'butter' but chooses margarine. The detective writes in his report that the man has bought margarine. The detective gives an account of the man's actions in terms of the evidence he himself has. By contrast, the man gives an account of his actions in terms of the reasons for actions that he himself has. However, the man knows his intentions or reasons for actions not on the basis of evidence that he has of himself. His reasons for acting actions or intentions are self-intimating or self-verifying. He acts from the deliberative or first-person perspective. There is an action according to reasons or an intention in doing something if there is an answer to the question 'Why?'. It is in terms of his own description of his action that we can grasp the reasons for the man's actions. In reply to the question 'Why did you buy margarine instead of butter?', the man might answer that he did so because it is better for his health. This answer, following Aristotle's theory of action, ${ }^{6}$ provides a reason for

\footnotetext{
5 Anscombe, E., Intention (Blackwell, 1957, 2nd edition 1963, reprinted by Harvard University Press, 2000).

6 Aristotle, Nichomachean Ethics I. i. 1094a1-5 (translated by H. Rackham, Cambridge: Harvard University Press, 1934). See also Aquinas, Summa Theologiæ, Ia2æ. 12, I. See also Kenny, A., Aristotle's Theory of the Will (London: Duckworth, 1979), Pasnau, R., Thomas Aquinas on Human Nature (Cambridge: Cambridge University Press, 2002), Finnis, J. Aquinas (Oxford: Oxford University Press, 1998) at pp. 62-71 and pp. 79-90. For contemporary formulations of the Aristotelian theory of action see Raz, J. "Agency, Reason and the Good". In: Engaging Reasons; Quinn, W., "Putting Rationality in Its Place". In: Morality and Action (Cambridge:
} 
action as a desirability or good-making characteristic. According to Anscombe the answer is intelligible to us and inquiries as to why the action has been committed stops. However, in the case of the detective when we ask 'Why did you write in the report that the man bought margarine?', the answer is that it is the truth about the man's actions. In the case of the detective, the knowledge is theoretical, the detective reports the man's actions in terms of the evidence he has of them. In the case of the man, the knowledge is practical. The reasons for action are self-verifying for the agent. He or she does not need to have evidence of his own reasons for acting. This self-intimating or self-verifying understanding of our own actions from the deliberative or practical viewpoint is part of the general condition of access to our own mental states that is called the 'transparency condition'. Its application to reasons for action can be formulated as follows:

(TC for reasons for actions) "I can report on my own reasons for actions, not by considering my own mental states or theoretical evidence about them, but by considering the reasons themselves which I am immediately aware of".

The direction of fit in theoretical and practical knowledge is also different. In the former case, my assertions need to fit the world whereas in the latter the world needs to fit my assertions. The detective needs to give an account of what the world looks like, including human actions in the world. He relies on the observational evidence he has. The detec-

Cambridge University Press) 1993, pp. 228-255; Thompson, M., Life and Action (Cambridge: Harvard University Press, 2008). For a criticism of the idea that a reason for action ought to be presented as a good-making characteristic, see Velleman, D., The Possibility of Practical Reason (Oxford: OUP, 2000), p. 118; Hursthouse, R. "Arational Actions". In: 57 Journal of Philosophy (1991), pp. 57-58; Stocker, M., "Desiring the Bad: An Essay in Moral Psychology", in The Journal of Philosophy (1979), pp. 738-753 and Setiya, K., Reasons Without Rationalism (Princeton: Princeton University Press, 2007), pp. 62-67. 
tive's description of the action is tested against the tribunal of empirical evidence. If he reports that the man bought butter instead of margarine, then his description is false. The man, by contrast, might say that he intended to buy butter and instead bought margarine. He changed his mind and asserts that margarine is healthier. There is no mistake here.

The agent knows the reasons for his actions without observation. This means that the reasons for actions are transparent to the agent. The knowledge that we have about the position of our body is not known mainly by observation; it might be aided by observation, but I do not need to take a theoretical or observational stance to know that my legs are crossed whilst I sit typing on my laptop. Anscombe tells us that intentional action is a sub-class of non-observational knowledge.

Gareth Evans in The Varieties of Reference refers to the phenomenon of 'transparency' that characterises beliefs:

In making a self-description of belief, one's eyes are, so to speak, or occasionally literally, directed outward -upon the world. If someone asks me 'Do you think there is going to be a Third World War?', I must attend, in answering him, to precisely the same outward phenomena as I would attend to if I were answering the question 'Will there be a Third World War'? I get myself in a position to answer the question whether I believe that $p$ by putting into operation whatever procedure I have for answering the question whether $p .{ }^{7}$

\section{Wittgenstein asserts:}

477 What does it mean to assert that 'I believe p' says roughly the same as 'p'? We react in roughly the same way when anyone says the first and when he says the second; if I said the first and someone didn't understand the words 'I

7 Evans, G., The Varieties of Reference (Oxford:OUP, 1982) at 225. See also Edgeley, R. Reason in Theory and Practice (London: Hutchinson and Co., 1969). 
believe', I should repeat the sentence in the second form, and so on.

478 Moore's paradox may be expressed like this: "I believe p" says roughly the same as 'p'; but 'Suppose I believe that p...' does not say the same as 'Suppose p...'

490 The paradox is this: the supposition may be expressed as follows: 'Suppose this went inside me and that outside'; but the assertion that this is going on inside me asserts: this is going on outside me. As suppositions the two propositions about the inside and the outside are quite independent, but not as assertions. ${ }^{8}$

For both Evans and Wittgenstein answers about whether I 'believe p' are outward-looking. I cannot answer the question whether I believe that it is raining, for example, without looking through the window, or reading the weather forecast. To answer such a question in terms of my introspective states seems absurd. We do not need to look inward at our states of mind to know whether or not it is raining.

Moran also advocates the 'transparency condition' but goes a step further in arguing that when I answer a question from a deliberative standpoint I need to "make up my mind' and this entails self-constitution. Following in the steps of Evans and Wittgenstein, Moran explains transparency as follows:

With respect of belief, the claim of transparency is that from within the first-person perspective, I treat the question of my belief about $\mathrm{P}$ as equivalent to the question of the truth of $\mathrm{P}$. What I think we can see now is that the basis for this equivalence hinges on the role of deliberative considerations about one's attitudes. For what the "logical" claim of transparency requires is the deferral of the theoretical question "What do I believe?" to the deliberative question "What am I to believe?"And in the case of the attitude of belief, answer-

8 Wittgenstein, L., Remarks on the Philosophy of Psychology, 1980 (Anscombe, E., translator, Oxford: Blackwell). 
ing a deliberative question is a matter of determining what is true. When we unpack the idea in this way, we see that the vehicle of transparency in each case lies in the requirement that I address myself to the question of my state of mind in a deliberative spirit, deciding and declaring myself on the matter, and not confront the question as a purely psychological one about the beliefs of someone who happens also to be me. ${ }^{9}$

For the purposes of this paper we do not need to engage with the dispute about the connection between self-knowledge and self-constitution. We can take the idea of transparency and see how it applies to reasons for actions. If I act intentionally $\mathrm{I}$ act according to reasons for actions, therefore I believe that I am acting intentionally for reasons as good-making characteristics, but if the transparency condition is sound, I do not need to look at my mental state to know whether I have the belief in my intentional action for reasons that for me are good-making characteristics, I just look outward to the facts, objects and state of affairs of the world. In this way, my belief that I am acting intentionally and that I have reasons for acting as good-making characteristics is transparent.

The detective makes a description of the man's actions and his statements are true or false in terms of what the man is doing. If the man fails to do what he intends to do, however, we do not say that the proposition the intends to $\varphi$ ' is false, rather we say that there is a mistake in performance. This is what Anscombe calls the "Theophrastus Principle', which states that in intentional action the mistake is not in judgment but in performance. Anscombe puts this as follows:

...as when I say to myself 'Now I press button A' - pressing button B- a thing which can certainly happen. This I will call the direct falsification of what I say. And here, to use

9 Moran, R., Authority and Estrangement (Princeton: Princeton University Press, 2001) at 62-3. 
Theophrastus' expression again, the mistake is not one of judgment but of performance. That is, we do not say: What you said was a mistake, because it was supposed to describe what you did and did not describe it, but: What you did was a mistake, because it was not in accordance with what you said. ${ }^{10}$

In the example "ADVICE FROM A FRIEND" when I say that I intend to get up early in the morning to go to the grocery store that sells the cheapest milk, I know that I intend to act for reasons, i.e. to save money to travel to South America. I do not need to look at my mental state to know that I have such reasons, I look outward to the world: my vehicle; the location and distance of the grocery store; the fact that the price of milk has risen; the fact that there is another grocery store within one mile where the milk is cheaper. I have groundless knowledge of my reasons for action. It is not incorrigible.

These facts guide me in my continuous series of actions and enable me to control my actions, i.e. to drive to the second store and wait until it has opened. Let us suppose that I discover that the price of the milk in the second store is not cheaper and that, therefore, my reason for driving there, i.e. that the milk is cheaper and I can save money, is mistaken. We say, thus, that there is a mistake in performance. I do not change my intention of saving money and travelling to South America, I change my actions and search for cheaper milk. However, the way I attain knowledge of my reasons for action does not depend on an inference from my observations or other data about myself. This entails that we have certain capacities, not only conceptual, but also practical.

I am able to exercise control over my actions because I can direct myself towards the end of my action as described by the reasons for actions as good-making characteristics and I can change the movements of my body if I discover,

10 Anscombe, E., Intention, §§32-33. 
aided by observation, that I am not doing what I intended to do (Theophrastus Principle). Thus, let us suppose that I am making an espresso when I find myself about to pour milk into the cup. I do not then say "I am not making an espresso after all, I am actually making a latte, that's alright". On the contrary, I change my movements and stop my action of pouring milk into the cup. The world fits my intentions; I transform the state of affairs through my actions to fit what I intend and I am committed to perform, whereas in theoretical knowledge my beliefs fit the world. In this way, I do not need observational knowledge to know that I intend to make an espresso, but I can be aided by observation to know the results of my intention.

Groundless knowledge of our reasons entails not only the capacity to act for reasons, but also includes knowing how to act intentionally according to reasons for actions in the specific context. But this does not mean that this groundless knowledge is not factive. On the contrary, it is knowledge about the world. Anscombe puts this as follows:

Say I go over to the window and open it. Someone who hears me moving calls out: What are you doing making that noise? I reply 'Opening the window'. I have called such a statement 'knowledge' all along; and precisely because in such a case what I say is true- I do open the window; and that means that the window is getting opened by the movements of the body out of whose mouth those words come. But I don't say the words like this: 'Let me see, what is this body bringing about? Ah yes! the opening of the window'.11

Our practical knowledge is also factual. When I intend to open the window and make the necessary movements with my hands, I know that I am opening the window and that I am actually opening the window.

Can we understand what we are doing because we $o b$ serve what we are doing? If we take a theoretical stance to-

11 Anscombe, E., Intention, §§28-29. 
wards our own actions, then we might argue that there is a kind of alienation concerning the identity of ourselves and our actions; in one sense the action is lost, because we do not look at the goal or object towards which our actions are directed, but we look at ourselves doing the action. We do not look outwards, but inwards and we lose the object or goal that we aim to bring about. Imagine that I am making an espresso and begin to reflect on the movements of my hands: I see myself putting coffee beans into the espresso machine, I see coffee flowing into the cup and smile at the thought of a fresh coffee. At some point it seems that I will lose the action of 'making an espresso'. It is impossible to be Narcissus. O'Shaughnessy asks whether this impossibility is really about the impossibility of doing two things at the same time, rather than a matter of the character of practical knowledge because if this is the case, then it is a quantitative matter and trivial. O'Shaugnessy argues that it is a matter of logic: "Just as I cannot be going north and south at the same time, so I cannot be reading a book and playing tennis at the same time". ${ }^{12}$

Thus, pathological cases are explained as the separation of the acting and the observing self.

Normativists cannot explain the complexity of the features of persistence and guidance that reasons for actions have. They privilege the justificatory story at the cost of leaving unexplained how the action unfolds, how the different parts of an action find unity in reasons for actions and reasons in action, and how the agent is able to persist and change his performance until he fulfills his intention because of the agent's reasons for action.

The second theory of reasons for action is the neoHumean theory which has a number of variations. Neo-Humeans privilege the explanatory view and argue that the explanation of action should be provided in terms of desires conceived as psychological or mental states.

12 O'Shaughnessy, B., "Observation and the Will", In: The Journal of Philosophy (1963), pp. 67-392, at 380. 
Neo-Humeans are able to explain the feature of explanation of reasons for action, ${ }^{13}$ but guidance, justification and persistence are left unexplained. Let us go back to our example of 'BUYING MILK': according to neo-Humeans, my reason of saving money and travelling to South America is grounded in the desire to save money and go travelling. The problem is that I have to be in this mental state when I drive to the two different grocery stores and when I persist in my action, and I need to 'look at' my mental state to know that my desires constitute my reasons for actions. We have seen the implausibility of taking a theoretical stance on your own mental states. Furthermore, problematic issues arise for this conception. Let us suppose that this routine of saving money through finding the best deal on bottles of milk extends for three years. Neo-Humeans need to explain how a desire as a pure mental state can persist over long periods of time. Neo-Humeans might need to rely on how much I value 'saving money' to explain the persistence of my action when I am in different mental states of desires, e.g. when I want to go on a spending spree. Do I need to remember my mental state, i.e. my desire to save money every time I act because of my desire?

Third, some authors argue that it is the structure of the action, specifically intentional action (Korsgaard, Anscombe) that constitutes the source of reasons for action. These authors privilege the explanatory principle not in terms of psychological explanations, but in terms of the deliberative and practical reasoning of the agent, and are able to show how in central cases the explanatory and the justificatory do not separate. Korsgaard relies on the practical identity of the agent whereas, arguably, Anscombe relies on facts created by public practices, values and practical realities that

13 Smith, M., 1987, "The Humean Theory of Motivation". In: Mind (1987): 36-61. 
might eventually provide the justificatory framework. ${ }^{14}$ Guidance and persistence can be explained by the structure of the practical reasoning of the agent.

Because Enoch's arguments are closer to normativist explanations of reasons for actions, I will concentrate on the normativist account. Like the normativists, Enoch privileges justificatory reasons for action, but he also has a causalist story that is in tension with it. I will discuss this in the following section.

\section{Putting Normativity in Its Place}

In 'BUYING MILK', according to the common sense view, you have reason to save money on your milk purchases because of your intention to save money and travel to South America. According to Enoch, the grocer has given you a reason to buy one bottle of milk instead of two. The grocer, Enoch tells us, has given you a reason to minimise your consumption of milk. He has manipulated the non-normative circumstances in such a way as to trigger a dormant reason "that was there all along independently of the grocer's actions". The reason of saving money was a dormant reason. In this scenario, let us call it "ENOCH-BUYING-MILK", your friend asks you why are you buying one bottle of milk instead of two and you answer: "because the grocer has raised the price of milk and this triggers my reason of saving money which, by the way, I have always had". When you are asked by your friend why you intend to save money, you would answer, according to Enoch, that you just have this normative reason for action and it was a dormant reason all along and the grocer's act of raising the price of the milk has triggered it. There are two parts to Enoch's argument. First, the grocer with his action transforms a non-normative fact (the price of the milk) into a

14 The meta-ethics of Anscombe's work in connection to her philosophy of action has been under-researched. See her article "Brute Facts". In: Analysis (1958), pp. 69-71. 
normative fact. But let us suppose that the girlfriend of your friend is with you in the grocery store and she does not care about saving money, and neither does your millionaire uncle nor your wealthy niece: they all intend to buy milk in your local grocery store. Has the grocer transformed a non-normative fact into a normative fact for all of them, i.e. for the girlfriend of your friend, your millionaire uncle and your wealthy niece? For Enoch the reason is there dormant for everyone, including the girlfriend of your friend, your millionaire uncle and your wealthy niece. But it is not a trigger for everyone. Furthermore, let us imagine the following example:

"FIRE AT HOME": You are at home with your two pets, Tookey the parrot and Bubble the dog, and there is a fire downstairs. Following Enoch's argumentative line, you have a normative reason for acting and leaving the house to escape and the reason, arguably, is there dormant. Is it also a dormant reason for action for Tookey and Bubble? How can Enoch distinguish between me, Tookey and Bubble? Arguably, Enoch might say, the world has dormant reasons for all creatures, including animals. A firefighter enters the lounge where you are sitting with Tookey and Bubble and orders you to escape.

According to Enoch, the firefighter has triggered a reason for action by giving you the order. Does he also trigger a reason for action for Tookey and Bubble? It would seem absurd to say this. Enoch needs therefore to restrict the scope of the reason-giving act. The restriction can be found in his defense of a Gricean theory of intention in the context of showing how robust reason-giving is a sub-species of triggering reason-giving. According to Gricean theory, intentions are mental states and we say, following Enoch, that A attempts to robustly give $\mathrm{B}$ a reason to $\varphi$ just in case (and because):

(i) A intends that B's reason to $\varphi$, and A communicates this intention to B;

(ii) A intends that $\mathrm{B}$ should recognise this intention; 
(iii) A intends that B's reason to $\varphi$ depends in an appropriate way on B's recognition of A's communicated intention to give $\mathrm{B}$ a reason to $\varphi$.

However, if intentions are mental states, how they can cause in the right sort of way the recognition of A's communicated intention? In other words, how can we recognise in the right way the mental states of others? Enoch reckons that deviant causal chains generate problems for all causalist accounts of mental states. He states that for robust reason-giving to occur, there must be a reason that exists prior to the attempt to give robust reasons and he states, concerning the condition of 'appropriate way':

I am not sure what more to say about the 'appropriate way' qualification in (iii). It is meant to rule out deviant causal (and perhaps other chains) chain. It would have been nice to have an account of how exactly to do this. But I will have to settle for noting that usually we know a deviant causal chain when we see one, and for claiming companions in guilt -for almost anyone needs an account of deviant causal chains. This qualification in (iii) thus doesn't make (iii) (or the account of which it is part) empty, nor does it raise any new problems that are peculiar to my account of robust reason-giving". 15

In the example of "FIRE AT HOME", the firefighter's orders give me a robust reason that exists independently of the firefighter's order. Arguably, for Tookey and Bubble the reason was there independently of the attempt at robust reason-giving by the firefighter. For 'Tookey' and 'Bubble', however, the reason has not been triggered because Tookey and Bubble could not recognise in the appropriate way -whatever this means- the intention of the firefighter. However, it seems absurd to say that Tookey and Bubble have reasons for actions, though dormant reasons for actions. Of course,

15 Enoch, D., "Giving Practical Reasons", see note 3 above, at 17. 
I am not saying that Enoch's account is committed to the view that facts in the world give reasons to all creatures, independently of their practical reasoning capacity. But he needs to explain how the facts of the world enter into our practical reasoning. In this way, he can restrict the scope of reason-giving. He needs to provide an account of reasons for action and reasons in action. The crucial part of the explanation remains unexplained i.e. how we as agents have reasons during the action. The notion of the 'appropriate way' aims to fill this explanatory gap, but it is left mysterious how this is done.

In his book Taking Morality Seriously, Enoch addresses the issue differently and for the second part of his argument he seems to argue that the belief in your reason for action causes the action. However, merely mental states such as beliefs cannot cause in the right way complex actions such as the drafting of a constitution, the enactment of the Human Rights Act, building cathedrals, writing novels, carving a sculpture and so on. These activities require the engagement of our intentions (the will) within successive actions and entail continuous practical efforts. The idea that only mental states, i.e. beliefs, are the causes of our intentional actions that persist over time is weakened by the view that mental states do not have the required stability and directiveness for such endeavours. The empirically mental causal story is too simple to explain and make intelligible the complexity of human endeavours. Furthermore, if Enoch is right, it is a mystery how you come to have this justificatory reason. One possible explanation is that it is mainly a theoretical exercise. Enoch asserts:

The way in which A's $\varphi$-ing can be responsive to R's being a normative reason, I suggested, was by being caused (in the appropriate way) by A's belief that $\mathrm{R}$ is a normative reason. ${ }^{16}$

16 Enoch, D., Taking Morality Seriously: A Defense of Robust Realism (Oxford: OUP) at 241. 
But if this is the case, the question that arises is how this belief can guide you and make you persist in your action. In "FIRE AT HOME", following the orders of the firefighter, I go upstairs and try unsuccessfully to open a window, I then run up to the roof the building and manage to jump down onto the firefighters' safety net.

According to Enoch, my performance of all of these actions is caused by my mental state of believing that there is a fire in the house and that the firefighter has triggered a dormant reason that I already had, i.e. to escape from the fire. Deviant causal chains plague these examples. Let us suppose that I am in the mental state of believing that there is fire in my house and the firefighter has triggered a reason that was dormant, i.e. to escape from the fire. However, I habitually experience an impulse to run up to the roof of my house and jump off. On this occasion, I merely followed my habitual impulse. I am in the mental state of believing that the firefighter has given me a reason, i.e. he has triggered a dormant reason for action, but it did not cause my action. What actually caused my action of jumping from the roof of my house was a habitual impulse.

Thus, guidance and control by reasons in actions and persistence in performance because of reasons in actions remain unexplained in the normativist view of Enoch's reason-giving. Can the world give you reasons without the intention to act and independently of your practical reasoning and practical capacities? Mere belief cannot make you to intend to act.

Enoch rejects the partial autonomy of the practical or deliberative domain and argues that we should blur the distinction between practical and theoretical reason. He complains that he does not understand the distinction between practical and theoretical reason and the role that the latter plays in forming and revising the relevant normative beliefs. He expresses his discomfort with the practical/theoretical distinction and recognizes his lack of understanding on the force of the distinction. We discover normative beliefs, 
Enoch tells us, by using our theoretical reason. According to Enoch, we do not need the notion of practical reason and it is unclear what it amounts to. If Enoch's view concerning practical reason is correct, what should we make of Enoch's claims about the first-person deliberative stance also defended in Taking Morality Seriously? If we decide to blur the distinction between practical and theoretical reason, why not also blur the distinction between the first-person deliberative and the third-person theoretical stance? Why not collapse the first-person deliberative perspective into the third-person theoretical point of view? According to Enoch, we use theoretical reason to form and revise our normative beliefs, and thus it appears that intentional action is a matter of 'being responsive to the relevant normative truths'.

Contrast this view, for example, with the views of Aristotle, Aquinas or Kant on the need to have 'an operative' principle or an arkhé for an agent to be engaged in action. For Aristotle, Aquinas and Kant, the relevant normative reason in action is formed by practical reason and the reason is in the action and when the agent acts. Like Aristotle, Aquinas and Kant, Enoch considers that we are the kind of creatures who respond to relevant normative reasons. Unlike Aristotle, Aquinas and Kant, however, Enoch does not consider that we respond on the basis of our practical capacities, i.e. practical reasoning. According to Enoch, my actions have been caused by my belief in the normative reasons involved in my action. It is mysterious, however, how actions are caused in the right way by my beliefs about normative truths without the participation of the agent's practical capacities and practical point of view. Let us suppose that I plan to make a sculpture: I buy the marble and start to work. One might conclude that for Enoch, the movements of my hand on the marble are caused in the right way by my belief in the beauty (normative truth) of my planned sculpture, but I am not the one who controls the movements. Enoch cannot explain how mere beliefs can control the movements of my hands and the persistence 
over time of my actions. Consider the following example: I lose my chisel and look for it in all the cabinets of my workshop, I go to the store to try to buy a chisel and realize that have no money or credit card to pay for the chisel. I return home to get some money, go back to the store and pay for the chisel. I return to my workshop and continue carving the sculpture. Arguably, for Enoch, this successive series of actions is caused in the right way by a mental state, i.e. a belief in the beauty of the planned sculpture. This is an implausible view and leaves mysterious how I have achieved the planned sculpture. It is also mysterious how I have obtained what I have intended, i.e. a sculpture with such and such dimensions, and with such and such features.

In my view, Enoch's extremely theoretical view entails the dissolution of our 'first-person deliberative experiences', i.e. the idea that I am the agent who moves (not that I am moved by my beliefs and therefore by some 'part' of me) and causes changes in the world according to what I intend and understand. Enoch seems too impatient with the deliberative/theoretical distinction and succumbs too quickly to the dominance of the theoretical domain.

It is trivially true to say that if we understand the phenomenon of reason-giving then we can pave the way to better understanding how legal directives and rules give us reasons for actions. But Enoch has not provided a satisfactory account of the phenomenon of reason-giving. Thus, we need to focus further on the phenomenology of legal directives, commands and rule-following in the light of moral psychology and philosophy of action to achieve a sound theory of what legal normativity amounts to in terms of how legal directives and legal rules provide reasons for actions. 
